Ufuk Ozgul*, Bayram Ozturk, Murat Kerkutluoglu, Oguzhan Yucel, Hasan Ata Bolayir, Filiz Alkan Baylan and Hakan Gunes

\title{
The predictive value of serum SCUBE-1 level for left ventricular thrombus in patients with post myocardial infarction heart failure
}

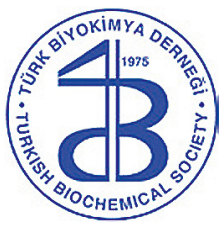

\section{Miyokard enfarktüsü sonrası kalp yetmezliği olan hastalarda sol ventrikül trombüsü için serum SCUBE-1 seviyesinin prediktif değeri}

https://doi.org/10.1515/tjb-2020-0600

Received December 13, 2020; accepted January 7, 2022;

published online February 3, 2022

\section{Abstract}

Objectives: Left ventricular thrombus is regarded as one of the main myocardial infarction complications. Knowing the left ventricular thrombus symptoms prevents serious complications that may occur. This study aims to reveal any association between SCUBE-1 and left ventricular thrombus, thought to be involved in platelet aggregation and adhesion.

Methods: The study included 80 patients diagnosed with heart failure following acute myocardial infarction, applying for the cardiology outpatient clinic for thirdmonth follow-up. The patients were included in two groups to see if the left ventricular thrombus was present. Thus, 22 patients were found to have left ventricular thrombus. The

*Corresponding author: Ufuk Ozgul, Cardiology, Aydın Atatürk State Hospital, Aydın, 09000, Turkey, E-mail: uozgul35@gmail.com.

https://orcid.org/0000-0001-5044-5663

Bayram Ozturk, Murat Kerkutluoglu and Hakan Gunes, Cardiology, Kahramanmaraş Sütcü Imam University, Kahramanmaraş, Turkey. https://orcid.org/0000-0001-7014-6484 (B. Ozturk). https://orcid.org/0000-0003-1007-0574 (M. Kerkutluoglu). https://orcid.org/0000-0003-3853-5046 (H. Gunes) Oguzhan Yucel, Cardiology, Yakin Dogu Universitesi Tip Fakultesi, Lefkosa, Cyprus. https://orcid.org/0000-0002-6076-9482 Hasan Ata Bolayir, Fırat University, Department of Cardiology, Elazığ, Turkey. https://orcid.org/0000-0002-3557-1175

Filiz Alkan Baylan, Biochemistry, Sütcü Imam University, Kahramanmaraş, Turkey. https://orcid.org/0000-0003-3117-7768 two groups were compared based on clinical laboratory and echocardiographic parameters.

Results: It was found that the patients with left ventricular thrombus had significantly higher Serum SCUBE-1 levels $(p<0.001)$. The optimal cutoff point of SCUBE-1 levels for predicting the LVT was $>35.1 \mathrm{~ms}$, with the specificity of $86 \%$ and sensitivity of $68.4 \%$ (AUC $=0.815 ; 95 \%$ CI, $0.699-0.931$; $\mathrm{p}<0.0001)$. SCUBE -1 level (OR=1.090, 95\% CI: 1.034-1.150, $\mathrm{p}<0.001)$ in the multiple logistic regression model continue to significantly predict LVT after adjusting for the confounding variables, as statistically significant in the univariate analysis of the variables which correlated with the SCUBE-1 levels.

Conclusions: SCUBE-1 level was determined to independently predict the left ventricular thrombus after a previous anterior myocardial infarction.

Keywords: acute myocardial infarction; left ventricular thrombus; LVT; SCUBE-1.

öz

Amaç: Sol ventrikül trombüsü, miyokard enfarktüsün ana komplikasyonlarından biri olarak kabul edilir. Sol ventrikül trombüsü semptomlarının bilinmesi oluşabilecek ciddi komplikasyonları önler. Bu çalışma, trombosit agregasyonu ve adezyonunda rol oynadığ düşünülen SCUBE -1 ile sol ventrikül trombüsü arasındaki herhangi bir ilişkiyi ortaya çıkarmayı amaçlamaktadır.

Gereç ve Yöntem: Akut miyokard enfarktüsü sonrası kalp yetmezliği tanısı alan ve üçüncü ay takibi için kardiyoloji polikliniğine başvuran 80 hasta çalışmaya alındı. Hastalar, sol ventrikül trombüsü olup olmadığını görmek için iki 
gruba ayrıldı. 22 Hastada sol ventrikül trombüsü tespit edildi. İki grup klinik laboratuvar ve ekokardiyografik parametrelere göre karşılaştırıldı.

Bulgular: Sol ventrikül trombüsü olan hastalarda serum SCUBE-1 düzeylerinin anlamlı düzeyde yüksek olduğu saptandı $(\mathrm{p}<0.001)$. SCUBE-1 seviyelerinin sol ventrikül trombüsünü tahmin etmek için optimal eşik değeriı, \%86 özgüllük ve \%68,4'lük duyarlılıkla >35.1 ms idi, (AUC=0.815; \%95 GA, 0.699-0.931; p<0.0001). Tek değişkenli analizde istatistiksel olarak anlamlı SCUBE-1 ile ilişkili gösterilen değişkenler, çoklu lojistik regresyon modelinde karıştırıcı değişkenler için düzeltme yapıldıktan sonra, SCUBE -1 seviyesi (OR=1.090, \%95 CI: 1.0341.150, p<0.001), LVT’yi önemli ölçüde tahmin etmeye devam etti.

Sonuç: SCUBE-1 seviyesinin, ön duvar miyokard enfarktüsünden sonra sol ventrikül trombüs gelişiminde bağımsız prediktör olduğu saptandı.

Anahtar kelimeler: Sol ventrikül trombüsü; SCUBE-1; Akut miyokard infarktüsü.

\section{Introduction}

Left ventricular thrombus (LVT) is one of the myocardial infarction (MI) main complications [1]. LVT has been reported relatively frequently, although recent progress has been made in the reperfusion strategy of increased ST-segment elevation myocardial infarction (STEMI) [2]. Recent studies pointed out that LVT incidence ranged between $2.5-15 \%$, but after acute anterior MI, this rate was found to be $23.5 \%$ [3-7]. LVT usually occurs when there is a left ventricular aneurysm (LVA) and LV apical akinesis, which develop after widespread anterior MI. Stasis and inflammatory processes in the aneurysm segment facilitate thrombus formation [8].

The superfamily of EGF is a set of growth factors, extracellular matrix proteins, and cytokine-like mediators. In 2002, a novel gene for an EGF-related protein was isolated in growing mice. A protein with a signal peptide at the amino-terminus is encoded by this new mammalian gene before one CUB (complementC1r/C1s) domain at the carboxyl terminus and several EGF (epidermal growth factor)-like repeats. Such a family of genes was called SCUBE-1 for proteins containing signal-peptide-CUB-EGFlike domain [9-11]. SCUBE-1 (protein 1 containing signal peptide-cub-EGF-like domain) has been identified in platelet-rich thrombus and atherosclerotic lesions. The recombinant fragments of SCUBE-1 were found to increase aggregation and adhesion of platelets $[12,13]$.
Platelets are activated by adhering to the subendothelial matrix, thus secreting SCUBE-1. Therefore, SCUBE-1, which acts as an endothelial adhesion molecule, plays a role in thrombus formation [14]. Due to myocyte necrosis after transmural $\mathrm{MI}$ and the inflammatory response, the sub-endocardial area becomes flat and weak. Platelets that adhere to the sub-endocardial matrix during the inflammatory process cause thrombus formation [8].

This study aimed to investigate the relationship between LVT and serum SCUBE-1 levels in patients suffering from heart failure after MI.

\section{Materials and methods}

\section{Study population}

This prospective observational study included 110 patients who had acute ST elevation MI and in the third-month follow-up in Research Hospital of Medical Faculty, University, between June 2020 and September 2020. The patients who were excluded from the study were those with ejection fraction (EF) above 45\%, essential thrombocytosis, chronic kidney disease, atrial fibrillation, mechanical prosthetic valve, severe valve pathologies, also those receiving warfarin and oral anticoagulant therapy, patients suffering from the acute coronary syndrome or patients who have a cerebrovascular event during the application process, and those with thromboembolic disease, protein C/S deficiency, patients with antiphospholipid antibody syndrome and paroxysmal nocturnal hemoglobinuria, and patients with the myeloproliferative disease. All patients included in the study were already receiving dual antiplatelet therapy at the initiation of the study. 95 of the patients were on ticagrelor + acetylsalicylic acid (ASA), 10 patients were on clopidogrel + ASA and 5 patients were on prasugrel + ASA combination therapy. Clopidogrel + oral anticoagulant treatment was started in these patients with intracardiac thrombus. Those who refused treatment were excluded from the study. Patients with no loss or no regression of intracardiac thrombus during the first 45 days of treatment were excluded. The follow-up of the intracardiac mass under treatment was used to confirm the diagnosis of thrombus. It was observed that the initial treatments of all patients included in the study were ticagrelor + ASA combination. According to these criteria, 80 patients suffering from heart failure after acute ST elevations and MI were included in the study. The patient's demographic and laboratory data were recorded. Echocardiographic examination was performed on all patients. Patients were included in two groups in terms of LVT.

Plasma SCUBE-1 assays: we performed a complete blood count and investigated routine biochemistry and cardiac enzymes from blood specimens collected from the patients and the controls. $2 \mathrm{~mL}$ of blood was also collected in citrate tubes from the patients and the controls once they were admitted to our hospital (before antiplatelet therapy and primary PCI procedure) for investigation. There was centrifugation of the specimens for $15 \mathrm{~min}$ in a 4000-cycle centrifuge device at $+4^{\circ} \mathrm{C}$. We placed serum ( $\left.1 \mathrm{cL} 3\right)$ in an Eppendorf tube and kept them at $-80{ }^{\circ} \mathrm{C}$ to perform the assay. We removed and put the Eppendorf tubes in a $+4{ }^{\circ} \mathrm{C}$ environment $24 \mathrm{~h}$ before the SCUBE- 1 evaluation. We gradually thawed Sera for more than $24 \mathrm{~h}$ and 
measured SCUBE-1 levels for the samples reaching room temperature. We used an enzyme-linked immunosorbent assay kit for the determination of SCUBE-1 levels as instructed by the manufacturer. We determined specimen absorbance on a VERSA max tunable microplate reader (Molecular Devices, Sunnyvale, CA, USA) at a wavelength of $450 \mathrm{~nm}$. We expressed the results as $\mathrm{ng} / \mathrm{mL}$.

\section{Standard echocardiography}

The experienced echocardiographers not knowing the clinical details of each subject used the Vivid $7^{\circledR}$ cardiac ultrasonography system (GE VingMed Ultrasound AS; Horten, Norway) with probes of 2.5 to $5 \mathrm{MHz}$ for transthoracic echocardiographic examinations. Each patient underwent 2D, pulsed, M-mode, and color flow doppler echocardiography examination based on the left supine and lateral positions. M-mode measurements and conventional Doppler echocardiographic examinations were based on criteria of the guideline issued by the European Society of Echocardiography [15]. 2D images and Doppler tracings of apical and subcostal views and parasternal long and short axes were used. The posterior and septal wall thicknesses, endsystolic and end-diastolic dimensions and left and right atrial dimension of the LV, and diastolic LV were measured. The left atrial volumes were measured using the disc method, and LV EF was used to estimate Simpson's rule. Diagnosis of LVT was due to visualization of an echo dense mass clearly separated from LV wall border at least in the 2 different orthogonal echocardiographic planes, near the area anterior wall of myocardium affected. Two experienced cardiologists were blinded to the angiographic data and evaluated the images.

\section{Statistical analysis}

Data were managed and analyzed with the SPSS software version 14 (SPSS Inc., Chicago, IL, USA) and it was found that a two-sided p-value $\leq 0.05$ was regarded as statistically significant. Where applicable, the number of cases and percentage and continuous variables as interquartile ranges (IQR), median, and mean \pm standard deviation (SD) were regarded as categorical variables. Univariate data were evaluated with the Kolmogorov-Smirnov test, while the homogeneity of variance was evaluated with the Levene test. In the comparison of the two groups, an independent two-sample t-test was used when the data showed normal distribution, and the Mann-Whitney U test was used when they did not show normal distribution. Effect sizes were calculated using the Cramer's $\mathrm{V}$ formula for the chi-square test, the Cohen scoring formula for the two-sample t-test, and the $\mathrm{z}$-score formula for the results obtained in the Mann-Whitney test. If appropriate, categorical data were evaluated using the chi-square test. Correlation analysis was done using the Spearman correlation test used for non-normally distributed variables and the Pearson correlation test for normally distributed variables. In the study correlation analysis, the relationships between scube- 1 level and proBNP and MPV were evaluated. Since monotonic relationships were observed between the variables, they were evaluated with Spearman's analysis. The optimal cut-off point of serum SCUBE-1 level was identified to predict LVT through ROC curve analysis. MedCalc was used for ROC curve analysis (v12.7.8). LVT was predicted to estimate the AUC with a 95\% confidence interval. The association between variables and LVT was quantified using the univariate analysis. It was found that the variables were statistically significant in the univariate analysis and the independent prognostic factors of LVT were determined using other potential confounders in the multivariate logistic regression model with the backward stepwise method. The effect of scube levels on predicting intracardiac thrombus development was demonstrated by post hoc power analysis. A post hoc analysis was applied for a retrospective power analysis and it was determined that a cohort size of 80 patients ( 22 with LVT and 58 without LVT) had a power of $\% 99.3$ to detect a difference at the 0.05 significance level. To avoid the risk of type 1 errors, post hoc pairwise comparisons were made for the Chisquare test. A two-tailed $\mathrm{p}$-value of $<0.05$ was accepted as statistically significant.

\section{Results}

Eighty patients with left ventricular failure after MI participated in the study. Of these patients, 70 were patients with acute anterior MI, and 10 were patients with acute MI history other than anterior MI. LVT was detected in 2 of 10 patients with acute MI other than anterior MI, 20 of the 70 patients with anterior MI, and 22 of all patients were included in the study. Also, LVAs were detected in 21 patients with anterior MI. LVT was seen in 11 patients with a LVA. Patients were included in two groups in terms of LVT. Table 1 shows clinical, echocardiographic, and laboratory data from the two groups. The group with LVT had a significantly higher rate of hypertension $(\mathrm{p}=0.019)$. However, no significant difference was found between the groups in age, smoking, gender, and diabetes mellitus rate. The standard echocardiographic measurements showed that the LVT group had a significantly higher left atrial diameter than the non-LVT group, while EF was significantly lower $(p=0.001, p=0.017)$. The LVT group had significantly higher laboratory parameters of SCUBE-1, NT-proBNP and LDL cholesterol $(\mathrm{p}=0.001, \mathrm{p}=0.002$, $\mathrm{p}=0.049$ ). Both groups had other similar laboratory parameters. Serum SCUBE-1 levels had a positive correlation with NT-proBNP and were found to be negatively correlated with MPV (Table 2).

The receiver operating characteristic (ROC) curve shows that the optimal cut-off point of SCUBE-1 levels used to predict LVT was $>35.1 \mathrm{~ms}$, with a sensitivity of $68.4 \%$ and specificity of $86 \%$ (AUC $=0.815$ 95\% CI, 0.699-0.931; $\mathrm{p}<0.001$ ) (Figure 1).

SCUCE-1 level (OR=1.090, 95\% CI: 1.034-1.150, $p<0.001)$, NT-proBNP (OR=1.001, 95\% CI: $1.000-1,002$. $\mathrm{p}=0.003$ ) and left atrial diameter(OR=1.406, 95\% CI: $1.124-$ 1,759. $\mathrm{p}=0.003$ ) in the multiple logistic regression model, continued to significantly predict LVT after adjusting for the confounding variables, as statistically significant in the univariate analysis of the variables which had correlation with the SCUBE-1 levels (Table 3). 
Table 1: Baseline characteristics of study patients.

\begin{tabular}{|c|c|c|c|c|}
\hline $\begin{array}{l}\text { Baseline } \\
\text { characteristics }\end{array}$ & $\begin{array}{r}\text { Left } \\
\text { ventricular } \\
\text { thrombus } \\
(n=22)\end{array}$ & $\begin{array}{r}\text { Without left } \\
\text { ventricular } \\
\text { thrombus } \\
\quad(n=58)\end{array}$ & $\begin{array}{r}\text { p- } \\
\text { Value }\end{array}$ & $\begin{array}{r}\text { Effect } \\
\text { size }\end{array}$ \\
\hline Age, years ${ }^{a}$ & $62 \pm 10$ & $58 \pm 13$ & 0.226 & 0.344 \\
\hline Male/female, $n^{*}$ & $18 / 4$ & $44 / 14$ & 0.766 & 0.064 \\
\hline Hypertension, n, \%* & $17(\% 77.3)$ & $26(\% 44.8)$ & 0.019 & 0.290 \\
\hline Smoker, n, \%* & $6(\% 27.3)$ & $28(\% 48.3)$ & 0.149 & 0.190 \\
\hline $\begin{array}{l}\text { Diabetes mellitus, } \\
\mathrm{n}, \%^{\star}\end{array}$ & $12(\% 54.5)$ & $19(\% 32.8)$ & 0.074 & 0.200 \\
\hline \multicolumn{5}{|l|}{ Laboratory data } \\
\hline $\mathrm{BUN}, \mathrm{mg} / \mathrm{dL}^{\mathrm{b}}$ & $16.5(8.25)$ & $15(9)$ & 0.319 & 0.065 \\
\hline Creatinine, $\mathrm{mg} / \mathrm{dL}^{\mathrm{a}}$ & $0.9 \pm 0.3$ & $0.9 \pm 0.2$ & 0.725 & 0.254 \\
\hline $\begin{array}{l}\text { Potassium, mmol/ } \\
\mathrm{L}^{\mathrm{a}}\end{array}$ & $4.3 \pm 05$ & $43 \pm 0.6$ & 0.834 & 0.552 \\
\hline Sodium, $\mathrm{mmol} / \mathrm{L}^{\mathrm{a}}$ & $137 \pm 3$ & $138 \pm 3$ & 0.395 & 0.333 \\
\hline $\begin{array}{l}\text { Total cholesterol, } \\
\mathrm{mg} / \mathrm{dL}^{\mathrm{b}}\end{array}$ & $157(64)$ & 55) & 0.857 & 0.051 \\
\hline $\mathrm{HDL}, \mathrm{mg} / \mathrm{dL}^{\mathrm{a}}$ & $39 \pm 7$ & $38 \pm 7$ & 0.590 & 0.142 \\
\hline $\mathrm{LDL}, \mathrm{mg} / \mathrm{dL}^{\mathrm{b}}$ & $126.5(64)$ & $108(54)$ & 0.049 & 0.213 \\
\hline $\begin{array}{l}\text { Triglycerides, mg/ } \\
\mathrm{dL}^{\mathrm{b}}\end{array}$ & $116.5(83)$ & $108(83)$ & 0.310 & 0.063 \\
\hline $\mathrm{D}$-dimer, $\mathrm{mg} / \mathrm{L}^{\mathrm{b}}$ & $0.300(0.4)$ & $0.360(0.35)$ & 0.316 & 0.149 \\
\hline Platelets, $10^{9} / \mathrm{L}^{\mathrm{a}}$ & $259.4 \pm 73$ & $265.7 \pm 78.6$ & 0.743 & 0.083 \\
\hline WBC, $10^{9} / \mathrm{L}^{\mathrm{a}}$ & $8.48 \pm 1.17$ & $8.87 \pm 1.45$ & 0.274 & 0.300 \\
\hline $\mathrm{RBC}, 10^{6} \mathrm{U} / \mathrm{L}^{\mathrm{a}}$ & $4.8 \pm 0.5$ & $4.8 \pm 0.5$ & 0.927 & - \\
\hline Hemoglobin, $\mathrm{g} / \mathrm{dL}^{\mathrm{a}}$ & $14 \pm 1.7$ & $13.8 \pm 1.7$ & 0.602 & 0.520 \\
\hline Hematocrit, $\%^{a}$ & $41.9 \pm 4.7$ & $41.2 \pm 4.0$ & 0.486 & 0.160 \\
\hline proBNP, $\mathrm{ng} / \mathrm{L}^{\mathrm{b}}$ & $2360(3836)$ & $852(1497)$ & 0.002 & 0.476 \\
\hline SCUBE-1, ng/mL ${ }^{\mathrm{a}}$ & $47.5 \pm 21.3$ & $22.6 \pm 15.2$ & $<0.001$ & 1.318 \\
\hline \multicolumn{5}{|c|}{ Echocardiography parameters } \\
\hline LV EF, $\%^{\mathrm{a}}$ & $32 \pm 5$ & $36 \pm 6$ & 0.017 & 0.724 \\
\hline $\begin{array}{l}\text { Left atrial diam- } \\
\text { eter, } \mathrm{cm}^{\mathrm{a}}\end{array}$ & $39.2 \pm 4.4$ & $35.5 \pm 4.3$ & 0.001 & 0.8500 \\
\hline $\begin{array}{l}\text { Septum } \\
\text { thickness, } \mathrm{mm}^{\mathrm{a}}\end{array}$ & $13.1 \pm 1.0$ & $9.8 \pm 1.4$ & 0.383 & 2.710 \\
\hline $\begin{array}{l}\text { Posterior wall } \\
\text { thickness, } \mathrm{mm}^{\mathrm{a}}\end{array}$ & $8.0 \pm 1.2$ & $8.47 \pm 1.1$ & 0.122 & 0.408 \\
\hline
\end{tabular}

${ }^{\mathrm{a}}$ Mean \pm standard deviation, ${ }^{\mathrm{b}}$ median (interquartile range), *chi-square ( $\mathrm{p} \leq 0.05$ was considered statistically significant). BUN, blood urea nitrogen; HDL, high-density lipoprotein; IQR, interquartile ranges; LDL, low-density lipoprotein; WBC, white blood cells; RBC, red blood cells; BNP, brain natriuretic peptide; LV, left ventricle.

Table 2: Correlation coefficients with SCUBE-1.

\begin{tabular}{lrr}
\hline Variables correlating with SCUBE-1 & $\boldsymbol{R}$ & p-Value \\
\hline Pro-BNP & 0.272 & 0.030 \\
MPV & -0.259 & 0.030 \\
\hline
\end{tabular}

BNP, brain natriuretic peptide; MPV, mean platelet volüme.

\section{Discussion}

The current study showed that serum SCUBE-1 level predicts LVT after the previous anterior MI, which is an independent predictor. We also found that NT-proBNP levels and left atrial diameters were independent predictors for LVT in these patients.

LVT is regarded as one of the prevalent complications in patients with acute anterior MI. Determining the presence of LVT can significantly prevent and treat embolic complications. Some clinical, echocardiographic, and angiographic parameters are markers of LVT in previous studies $[4,16]$. But there are not enough studies on this subject at the molecular level. The prolonged ischemia in STEMI leads to sub-endocardial and endothelial damage while increasing procoagulant factors concentration. The akinetic areas of the resulting necrotic myocardium result in blood stasis, particularly at the apex of the left ventricle [17]. In addition, after MI, necrotic tissues replace with fibrotic scar tissue over time, causing myocardial tissue weakening. This thinning of the myocardial tissue may lead to aneurysms $[16,18]$. Myocardial tissue with reduced wall thickness expands during systole, causing the contractile energy generated by the myocardium to be wasted. This causes mechanical damage to the entire ventricle $[19,20]$. This may facilitate thrombus formation by causing intraventricular stasis and endocardial damage [21]. The inflammatory process associated with subendothelial and endothelial damage triggers the activation of platelets and contributes to thrombus formation [17]. SCUBE-1 is a new adhesion molecule found in human endothelial platelets and cells. There is a normal storage of SCUBE-1 protein in platelet alpha granules transported to the surface through thrombin activation [10-12]. SCUBE-1 protein is also integrated with the growing thrombus [13]. Platelet-platelet interaction is also promoted by the molecule, playing a role in platelet adhesion to the subendothelial matrix [22-25]. SCUBE-1 levels may be important in platelet adhesion and platelet aggregation to the subendothelial and endothelial damaged area of the left ventricle after MI. Serum SCUBE-1 levels were also high in acute coronary syndromes and thromboembolic cerebrovascular diseases [22, 26]. Similarly, the present study showed high serum SCUBE-1 levels in patients with LVT.

Stretched myocytes synthesized and secreted NTproBNP mainly through volume expansion or overpressure charge of the ventricle [27-30]. NT-proBNP is considered as the most reliable and valuable biomarker of cardiac dysfunction in heart failure [31, 32]. It has been 


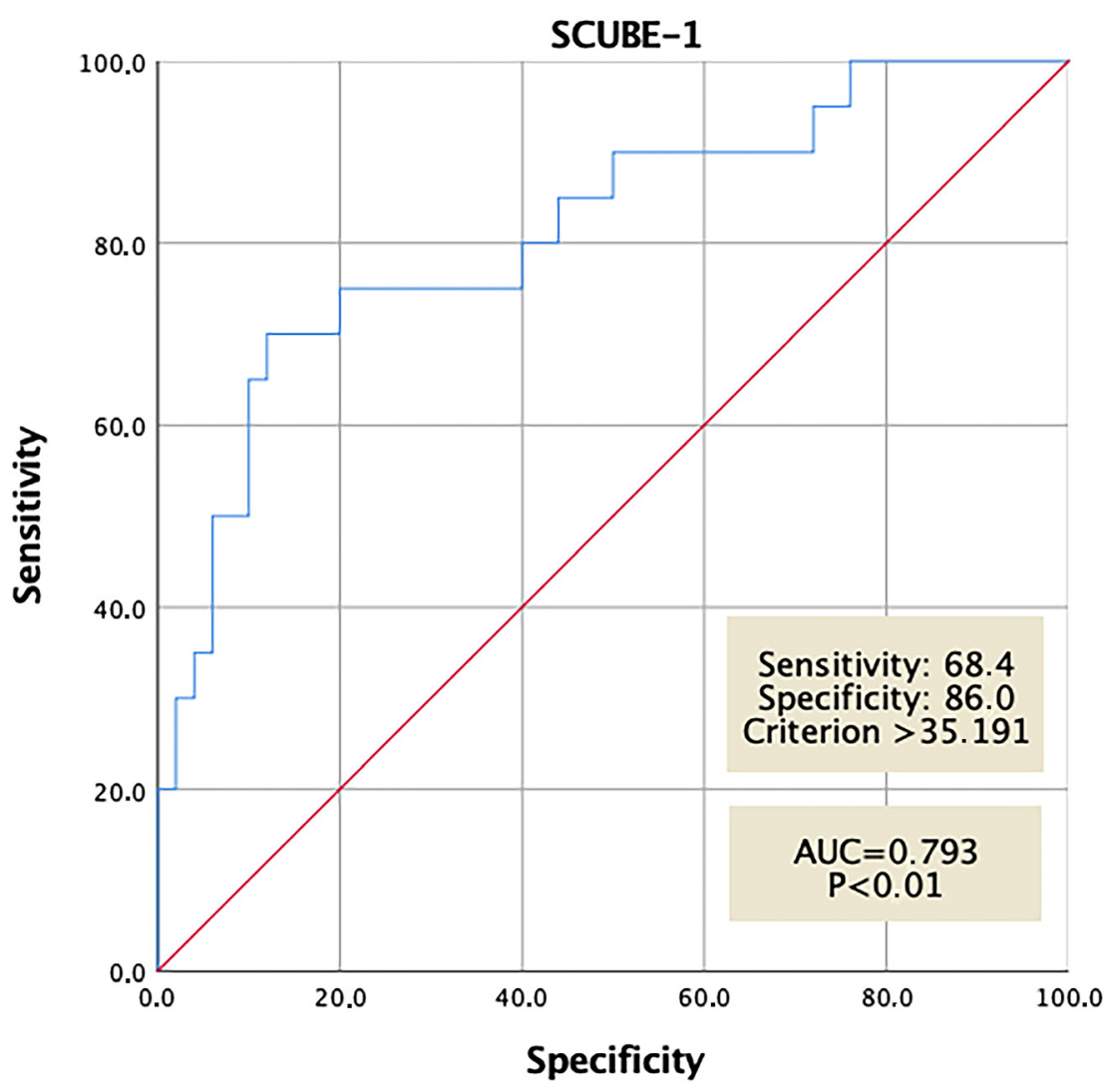

Figure 1: Receiver operator characteristic (ROC) curve of SCUBE-1 level to predict LVT.

Table 3: Univariate and Multivariate analysis.

\begin{tabular}{|c|c|c|c|c|c|c|c|c|c|c|c|c|}
\hline \multirow[t]{2}{*}{ Variables } & \multicolumn{6}{|c|}{ Univariate analysis } & \multicolumn{6}{|c|}{ Multivariate analysis } \\
\hline & B & SE & WALD & p-Value & OR & $\mathrm{Cl}$ & B & SE & WALD & p-Value & OR & $\mathrm{Cl}$ \\
\hline Serum SCUBE-1 level & 0.900 & 0.030 & 9.110 & 0.003 & 1.094 & $1.032-1.160$ & 0.086 & 0.027 & 10.093 & 0.001 & 1.090 & $1.034-1.150$ \\
\hline Pro-BNP & 0.001 & 0.000 & 8.011 & 0.005 & 1.001 & $1.000-1.002$ & 0.001 & 0.000 & 9.121 & 0.003 & 1.001 & $1.000-1.002$ \\
\hline Left atrial diameter & 0.566 & 0.219 & 6.690 & 0.010 & 1.761 & $1.147-2.703$ & 0.341 & 0.114 & 8.896 & 0.003 & 1.406 & $1.124-1.759$ \\
\hline LV EF & -0.41 & 0.092 & 0.200 & 0.655 & 0.960 & $0.802-1.149$ & & & & & & \\
\hline Hypertension & 2.987 & 1.856 & 2.591 & 0.107 & 19.829 & $0.522-753.310$ & & & & & & \\
\hline \multicolumn{13}{|c|}{ Variables correlating with SCUBE-1 } \\
\hline MPV & -0.282 & 0.206 & 1.879 & 0.170 & 0.754 & $0.504-1.129$ & & & & & & \\
\hline
\end{tabular}

Pro-BNP, pro b-type natriuretic peptide; LV, left ventricle; MPV, mean platelet volume.

demonstrated in many studies that left ventricular dysfunction is a predictor of LVT $[6,33]$. We found that the LVT group had significantly higher NT-proBNP, a biomarker of heart failure, and independently predicted the LVT. However, although EF was significantly lower in LVT, it was found to be not an independent predictor. The reason for this can be explained by the involvement of patients of heart failure with EF that is below $45 \%$ in the research.

The left atrium is highly effective in cardiovascular homeostasis due to its important duty in regulating cardiac filling. Left atrial remodeling and the increase in left atrial volume often occur with hypertension, pulmonary diseases, ischemia, and heart failure [34]. Cardiovascular events and thromboembolic events are also prognostic markers, especially in atrial fibrillation due to remodeling. However, cardiovascular risk and thromboembolic events are also associated with an increase in atrial dilation, which exists without atrial fibrillation, independent of other risk factors and comorbid events [35]. This situation is explained by atrial cardiomyopathy. Endothelial dysfunction and hypercoagulability in atrial cardiomyopathy contribute to LVT formation [36]. Similarly, left atrial dilation was found to independently predict the LVT in the present study. 


\section{Limitations of the study}

This study has one main limitation, which is the determination of LVT presence. Echocardiography was used to determine if the LVT was present, and studies were showing that cardiac MRI was more sensitive in the LVT diagnosis. In this study, patients assumed to be suboptimal were evaluated with transesophageal echocardiography (TEE), and patients who did not consent to TEE were excluded. In patients who do not consent to TEE, the absence of contrast Echo is another limitation. In addition, echocardiographic control was done to determine if the LVT was present in the third month, which is another limitation. The fact that serum SCUBE-1 levels are also affected by various physiological variables can also be considered a limitation.

\section{Conclusions}

LVT is regarded as one of the prevalent complications of acute MI. Identifying LVT predictors is important for both prevention of complications and the determination of treatment strategy. Serum SCUBE-1 levels can be used as a simple, easily accessible biomarker to predict LVT.

Research funding: None declared.

Author contributions: All authors have accepted responsibility for the entire content of this manuscript and approved its submission.

Competing interests: Authors state no conflict of interest. Informed consent: Not applicable.

Ethical approval: Not applicable.

\section{References}

1. Gökdeniz T, Boyacı F, Hatem E, Aslan AO, Aykan AÇ, Gül I, et al. SYNTAX score predicts the left ventricle thrombus development in patients undergoing primary percutaneous coronary intervention for first anterior myocardial infarction. Clin Appl Thromb Hemost 2014;20:698-705.

2. Gianstefani S, Douiri A, Delithanasis I, Rogers T, Sen A, Kalra S, et al. Incidence and predictors of early left ventricular thrombus after ST-elevation myocardial infarction in the contemporary era of primary percutaneous coronary intervention. Am J Cardiol 2014;113:1111-6.

3. Sharma ND, McCullough PA, Philbin EF, Weaver WD. Left ventricular thrombus and subsequent thromboembolism in patients with severe systolic dysfunction. Chest 2000;117:314-20.

4. Nesković AN, Marinković J, Bojić M, Popović AD. Predictors of left ventricular thrombus formation and disappearance after anterior wall myocardial infarction. Eur Heart J 1998;19:908-16.
5. Zhang Q, Wang CM, Shi ST, Chen H, Zhou YJ. Relationship of left ventricular thrombus formation and adverse outcomes in acute anterior myocardial infarction in patients treated with primary percutaneous coronary intervention. Clin Cardiol 2019;42:69-75.

6. Zielinska M, Kaczmarek K, Tylkowski M. Predictors of left ventricular thrombus formation in acute myocardial infarction treated with successful primary angioplasty with stenting. Am J Med Sci 2008;335:171-6.

7. Porter A, Kandalker H, lakobishvili Z. Left ventricular mural thrombus after anterior ST-segment elevation acute myocardial infarction in the era of aggressive reperfusion therapy still a frequent complication. Coron Artery Dis 2005;16:275-9.

8. Ruzza A, Czer LSC, Arabia F. Left ventricular reconstruction for postinfarction left ventricular aneurysm: review of surgical techniques. Tex Heart Inst J 2017;44:326-35.

9. Yang RB, Ng CK, Wasserman SM, Colman SD, Shenoy S, Mehraban F, et al. Identification of a novel family of cell-surface proteins expressed in human vascular endothe-lium. J Biol Chem 2002;277:46364-73.

10. Wu BT, Su YH, Tsai MT, Wasserman SM, Topper JN, Yang RB. Anovel secreted, cell-surface glycoprotein containing multiple epidermal growth factor-like repeats and one CUB domain is highly expressed in primary osteoblasts and bones. J Biol Chem 2004:279:37485-90.

11. Dai DF, Thajeb P, Tu CF. Plasma concentration of SCUBE1, a novel platelet protein, is elevated in patients with acute coronary syndrome and ischemic stroke. J Am Coll Cardiol 2008;51:2173-80.

12. Tu CF, Su YH, Huang Y, Tsai MT, Li LT, Chenet YL, et al. Localization and characterization of novel secreted protein SCUBE1 in human platelets. Cardiovasc Res 2006;71:486-95.

13. Bolayır HA, Kıvrak T, Güneş H, Akaslan D, Şahin Ö, Bolayır A. The role of SCUBE1 in the development of late stent thrombosis presenting with ST-elevation myocardial infarction. Rev Port Cardiol 2018;37:375-81.

14. Lang RM, Bierig M, Devereux RB, Flachskampf FA, Foster E, Pellikka PA, et al. Recommendations for chamber quantification: a report from the American Society of Echocardiography's guidelines and standards committee and the chamber quantification writing group, developed in conjunction with the European association of echocardiography, a branch of the European Society of Cardiology. J Am Soc Echocardiogr 2005;18: 1440-63.

15. Gunes H, Sokmen A, Kaya H, Gungor O, Kerkutluoglu M, Guzel FB, et al. Evaluation of atrial electromechanical delay to predict atrial fibrillation in hemodialysis patients. Medicina 2018;54:58.

16. Keeley EC, Hillis LD. Left ventricular mural thrombus after acute myocardial infarction. Clin Cardiol 1996;19:83-6.

17. Delewi R, Zijlstra F, Piek JJ. Left ventricular thrombus formation after acute myocardial infarction. Heart 2012;98:1743-9.

18. Garcia-Guimaraes M, Velasco-Garcia-de-Sierra C, Estevez-Cid F, Perez-Cebey L, Bouzas-Mosquera A, Mendez-Eirin E, et al. Current role of cardiac imaging to guide surgical correction of a giant left ventricular pseudoaneurysm. Int J Cardiol 2015;198: 152-3.

19. Ruzza A, Czer LSC, Arabia F, Vespignani R, Esmailian F, Cheng W, et al. Left ventricular reconstruction for postinfarction left ventricular aneurysm: review of surgical techniques. Tex Heart Inst J 2017;44:326-35.

20. Marzlin KM. Ventricular aneurysm: diagnosis and treatment. AACN Adv Crit Care 2017;28:391-4. 
21. McCarthy CP, Vaduganathan M, McCarthy KJ, Januzzi JL Jr., Bhatt DL, McEvoy JW. Left ventricular thrombus after acute myocardial infarction: screening, prevention, and treatment. JAMA Cardiol 2018;3:642-9.

22. Ferroni P, Riondino S, Vazzana N, Santoro N, Guadagni F, Davìet G. Biomarkers of platelet activation in acute coronary syndromes. Thromb Haemostasis 2012;108:1109-23.

23. Tu CF, Yan YT, Wu SY, Djoko B, Tsai MT, Cheng CJ, et al. Domain and functional analysis of a novel platelet-endothelial cell surface protein, SCUBE1. J Biol Chem 2008;283:12478-88.

24. Wu MY, Lin YC, Liao WJ, Tu CF, Chen MH, Roffler SR, et al. Inhibition of the plasma SCUBE1, a novel platelet adhesive protein, protects mice against thrombosis. Arterioscler Thromb Vasc Biol 2014;34: 1390-8.

25. Acıpayam C, Tuncel DA, Güneş H, Akkececi NS, Tolun FI, İpek S, et al. Investigation of SCUBE-1 levels in pediatric patients with beta thalassemia. J Surg Med 2019;3:825-8.

26. Turkmen S, Eryigit U, Karaca Y, Mentese A, Sumer UA, Yulug E, et al. Diagnostic value of plasma signal peptide-Cub-Egf domaincontaining protein-1 (SCUBE-1) in an experimental model of acute ischemic stroke. Am J Emerg Med 2015;33:262-5.

27. Clerico A, Recchia FA, Passino C, Emdin M. Cardiac endocrine function is an essential component of the homeostatic regulation network: physiological and clinical implications. Am J Physiol Heart Circ Physiol 2006;290:17-29.

28. De Lemos JA, McGuire DK, Drazner MH. B-type natriuretic peptide in cardiovascular disease. Lancet 2003;362:316-22.

29. Rodeheffer RJ. Measuring plasma B-type natriuretic peptide in heart failure: good to go in 2004? J Am Coll Cardiol 2004;44: 740-9.
30. Levin ER, Gardner DG, Samson WK. Natriuretic peptides. N Engl J Med 1998;339:321-8.

31. Ponikowski P, Voors AA, Anker SD, Bueno H, Cleland JG, Coats AJ, et al. ESC guidelines for the diagnosis and treatment of acute and chronic heart failure: the task force for the diagnosis and treatment of acute and chronic heart failure of the European Society of Cardiology (ESC). Developed with the special contribution of the Heart Failure Association (HFA) of the ESC. Eur J Heart Fail 2016;18:891-975.

32. Yancy CW, Jessup M, Bozkurt B, Butler J, Casey DE, Drazner MH, et al. ACCF/AHA guideline for the management of heart failure: a report of the American college of cardiology foundation/ American heart association task force on practice guidelines. J Am Coll Cardiol 2013;62:147-239.

33. Shacham Y, Leshem-Rubinow E, Ben Assa E, Rogowski O, Topilsky Y, Roth A, et al. Frequency and correlates of early left ventricular thrombus formation following anterior wall acute myocardial infarction treated with primary percutaneous coronary intervention. Am J Cardiol 2013;111:667-70.

34. Polovina MM, Coats A, Seferovic P. Is the left atrium the best kept secret of the heart? Left atrial dilatation and cardiovascular outcomes. Heart 2019;105:1848-9.

35. Froehlich L, Meyre P, Aeschbacher S, Blum S, Djokic D, Kuehne M, et al. Left atrial dimension and cardiovascular outcomes in patients with and without atrial fibrillation: a systematic review and meta-analysis. Heart 2019;105:1884-91.

36. Goette A, Kalman JM, Aguinaga L, Akar J, Cabrera JA, Chen SA, et al. EHRA/HRS/APHRS/SOLAECE expert consensus on atrial cardiomyopathies: definition, characterization, and clinical implication. Europace 2016;18:1455-90. 